\title{
Studies on the reduction of organic load from palm oil mill effluent (POME) by bacterial strains
}

\author{
Jeremiah David Bala • Japareng Lalung • \\ Norli Ismail
}

Received: 6 May 2014/ Accepted: 26 November 2014/Published online: 16 December 2014

(c) The Author(s) 2014. This article is published with open access at Springerlink.com

\begin{abstract}
Introduction Palm oil mill effluent (POME) contains large quantities of organic matter in the form of total suspended solids (TSS), volatile suspended solids (VSS), total solids (TS), oil and grease ( $\mathrm{O} \& \mathrm{G}$ ) that increase biochemical oxygen demand (BOD) and chemical oxygen demand (COD) of POME if left untreated. The main aim of the present study was to investigate the ability of bacterial strains either pure (individually) or mixed (combinations), to degrade and metabolize organic load from palm oil mill effluent.

Results Sequencing of the 16S rRNA of the isolates suggests that they were identified as Micrococcus luteus 101 PB, Stenotrophomonas maltophilia 102 PB, Bacillus cereus 103 PB, Providencia vermicola 104 PB, Klebsiella pneumoniae $105 \mathrm{~PB}$ and Bacillus subtilis $106 \mathrm{~PB}$. The use of mixed cultures in the present study showed more extensive removal of organic load (COD and BOD) than pure single cultures. Mixed cultures were found to reduce the pollutant dynamically. Thus, the mixed cultures $\mathrm{C}_{1}$ (Bacillus cereus $103 \mathrm{~PB}$ and Bacillus subtilis $106 \mathrm{~PB}$ ) were the most effective bacterial combination for use in biological treatment technology of POME having the highest $C O D$ and $B O D$ reduction rate. $C_{1}$ produced the
\end{abstract}

\footnotetext{
J. D. Bala $\cdot$ J. Lalung $\cdot$ N. Ismail $(\bowtie)$

Environmental Technology Division, School of Industrial

Technology, Universiti Sains Malaysia (USM), 11800 Pulau,

Pinang, Malaysia

e-mail: norlii@usm.my

J. D. Bala

e-mail: Jerrybrown316@yahoo.com

J. Lalung

e-mail: japareng@usm.my
}

highest degradative activity in reducing COD (90.64\%) and BOD $(93.11 \%)$.

Conclusion The indigenous microbial isolates from POME were observed to possess potential to degrade organic components whereas the use of mixed cultures resulted in more extensive degradation of COD and BOD than pure single cultures. This suggests that mixed culture of bacteria in the present study can be used for bioremediation of environment contaminated with polluted wastewaters. This study, however, indicates the prospect of isolating indigenous microorganisms in the POME for effective biotreatment of POME.

Keywords Bacteria - BOD - COD - Organic load . POME - Reduction - Treatment - Wastewater

\section{Introduction}

Palm oil industry is one of the leading agricultural industries in Malaysia with average crude palm oil production of more than 13 million tonne per year. However, production of such huge amount of crude palm oil has consequently resulted to even larger amount of palm oil mill effluent (POME). POME is a highly polluting wastewater with high chemical oxygen demand (COD) and biochemical oxygen demand (BOD) which can cause severe pollution to the environment, typically pollution to water resources (Lam and Lee 2011). The palm oil industry is identified as one of the agricultural industries in Malaysia that generates the highest pollution load into rivers throughout the country (Wu et al. 2007). Although POME is a non-toxic liquid waste with unpleasant smell, its COD and BOD values are high enough to cause serious pollution and environmental problem to the rivers. Chin et al. (1996) have reported that 
POME contains a high concentration of organic matter, COD concentration in the range of $45,000-65,000 \mathrm{mg} / \mathrm{L}$ and BOD of $18,000-48,000 \mathrm{mg} / \mathrm{L}$. COD in the range of $80,100-95,000 \mathrm{mg} / \mathrm{L}$ and BOD of $23,400-52,100 \mathrm{mg} / \mathrm{L}$ has also been encountered (Soleimaninanadegani and Manshad 2014).

The high COD value is responsible for distraction of aquatic life (Maygaonkar et al. 2012). Generally, COD and BOD are essential parameters used as indicators of composition and environmental impact of wastewaters (Jameel et al. 2011). Oil and grease are considered as hazardous pollutants particularly in the aquatic environments, since they are highly toxic to the aquatic organisms and can completely damage the ecology of the aquatic ecosystem. When discharged into the environment, it may have objectionable odour, cause undesirable appearance, burn on the surface of receiving water creating potential hazards and consume dissolved oxygen necessary to forms of life in water (Jameel and Olanrewaju 2011). Suspended solids can clog fish gills, either killing them or reducing their growth rate. They also reduce light penetration. This reduces the ability of algae to produce food and oxygen. POME contains higher concentrations of various pollutants and such may be categorized as a high strength wastewater which required effective treatment before being discharged into the environment.

Very few investigations have been conducted on aerobic digestion process for the treatment of organic pollutants present in POME (Wu et al. 2010). Therefore, this work represents one of the few studies on the aerobic biotreatment technology of POME-contaminated wastewater in Malaysia.

Biological treatment of POME by Yarrowia lipolytica NCIM 3589 has been studied (Oswal et al. 2002). Abass et al. (2012) and Soleimaninanadegani and Manshad (2014) have also reported aerobic digestion of POME by selected microorganisms. Treatment of POME has been variously reported by other workers (Sinnappa 1978; Agamuthu et al. 1986; Chin et al. 1996; Mohammed et al. 2014).

The anaerobic digestion treatment of POME using various types of bioreactors by researchers and the ponding systems in the mills uses unknown microbial populations (McHugh et al. 2003) to reduce the polluting power of wastes and wastewaters. This involves a consortium of unknown microorganisms catalyzing a complex series of biochemical reactions that mineralize organic matter producing methane and carbon dioxide. These microorganisms are not established and hence the substrate they degrade and utilize is not ascertained.

In the present study, known microorganisms were isolated from POME, which were further used to inoculate the POME. The efficiency for organic load reduction and the percent reduction was monitored. Therefore, so far to the best of our knowledge no work has been done on the isolation of different aerobic microorganisms in POME. This emphasizes the originality of the study.

The application of microorganisms such as Trichoderma viride spores, T. viride mycelium, Yarrowia lipolytica and Saccharomyces cerevisiae for the treatment of POME was not that effective in organic load reduction (Jameel and Olanrewaju 2011). This may be due to the fact that these microorganisms are not indigenous to POME (Jameel and Olanrewaju 2011). This gap offered researchers a greater opportunity to explore the organic load reduction of POME by their indigenous (autochthonous) isolates. These are organisms that exist/occur naturally in a particular biophysical environment.

Hence, serious measures have to be taken to prevent the growing pollution and ecological degradation related to POME. The aim of the present study was to investigate the ability of bacterial strains either pure (individually) or mixed (combinations), isolated from POME to degrade and metabolize organic load from POME.

\section{Materials and methods}

Sample collection

Raw palm oil mill effluent was collected from the site of a palm oil mill industry in a sterile container and brought back to the laboratory. The sample was transported to the laboratory in an ice box and analyzed for microbiological and physicochemical properties within $4 \mathrm{~h}$ of collection. The physicochemical characteristics of the sample were determined in accordance with the standard methods published by American Public Health Association (APHA 2005).

\section{Sample preservation}

The POME was preserved at a temperature less than $4{ }^{\circ} \mathrm{C}$, to prevent the wastewater from undergoing biodegradation due to microbial action (APHA 2005).

\section{Microorganisms}

Four isolates (Micrococcus luteus $101 \mathrm{~PB}$, Stenotrophomonas maltophilia $102 \mathrm{~PB}$, Bacillus cereus $103 \mathrm{~PB}$, and Bacillus subtilis $106 \mathrm{~PB}$ ) were selected for POME inoculation and treatment based on the criteria that they were able to display good growth and degradation of oil and cellulose as sole source of carbon and energy in MSM from our previous work (Bala et al. 2014). The isolates were identified by sequence analysis of $16 \mathrm{~S}$ rRNA genes. Sequences of primers used are: 


\section{F: 5'-AGAGTTTGATCMTGGCTCAG-3'}

\section{R: 5'-GGGTTACCTTGTTACGACTT-3'}

Plates 1 and 2 show genomic DNA and purified PCR product of bacteria isolated from POME inclusive of two others isolates which did not fulfil the criteria of the present study.

Analytical methods and characterization of POME

The following parameters BOD, COD, TSS, oil and grease were analyzed by standard methods (APHA 2005) for 5 days. These analyses were carried out according to the standard procedures (APHA 2005). Characterization of the POME was carried out before and after the treatment to determine the efficiency of the treatment. All the experiments were performed in triplicates.

\section{Experimental procedure}

\section{Inoculation of POME with bacterial isolates}

Using combination of bacterial strains The following bacterial combinations were investigated (in four laboratory batch-scale reactors inclusive of one control reactor) to determine which combination could produce the maximum organic load reduction. These include $\mathrm{C}_{1}$ combination (consisting of Bacillus cereus $103 \mathrm{~PB}$ and Bacillus subtilis $106 \mathrm{~PB}$ ) and $\mathrm{C}_{2}$ combination (consisting of Micrococcus luteus $101 \mathrm{~PB}$ and Stenotrophomonas maltophilia $102 \mathrm{~PB}$ ). Four percent inoculum containing $10^{6}$ cells $/ \mathrm{mL}$ with an optical density (OD) of 1.2 at $600 \mathrm{~nm}$ of each bacterial isolates was added into $250 \mathrm{~mL}$ of POME sample without addition of nutrients. They were incubated at $37^{\circ} \mathrm{C}$ and at $150 \mathrm{rpm}$ shaking speed. Bacterial cultures were incubated under aerobic conditions at $37{ }^{\circ} \mathrm{C}$ and agitated at $150 \mathrm{rev} /$ min. Samples were then aseptically drawn from mixtures every $24 \mathrm{~h}$ for 5 days and analyzed for BOD, COD, TSS, oil and grease and $\mathrm{pH}$ from each combinations. Cell count was determined by serial dilution method of samples on nutrient agar plates and incubated at $37{ }^{\circ} \mathrm{C}$ for $24 \mathrm{~h}$. Control reactor was not inoculated. Eight percent (8\%) of each inoculum containing $10^{6}$ cells $/ \mathrm{mL}$ with an optical density (OD) of 1.2 at $600 \mathrm{~nm}$ was used for pure/single bacterial strains. All the experiments were performed in triplicates. The efficiency for organic load reduction and the percent reduction was measured using the following equation (Piro et al. 2011). COD, BOD, TSS, oil and grease contents were analyzed with standard method (APHA 2005) and presented as percent reduction.

Reduction $(\%)=100-\left[\frac{C_{\text {raw POME }}-C_{\mathrm{f}}}{C_{\text {raw POME }}} \times 100\right]$ where $C_{\text {raw POME }}$ is the concentration of $\mathrm{COD}, \mathrm{BOD}_{5}$, TSS and oil $\&$ grease of raw POME and $C_{\mathrm{f}}$ the concentration of these parameters after treatment. Each set of these experiments was done in triplicates.

\section{Results and discussion}

Palm oil mill effluent (POME) characteristics

Raw POME collected from the palm oil mill was thick, brownish in colour, colloidal suspension, dark, oily and viscous with an obnoxious odour. The raw sample consists of high COD concentration up to $75,900 \mathrm{mg} / \mathrm{L}$, BOD $34,393 \mathrm{mg} / \mathrm{L}$, TSS $14,467 \mathrm{mg} / \mathrm{L}$, oil \& grease $191 \mathrm{mg} / \mathrm{L}$ and pH 4.74 as depicted in Table 1. In comparison, other investigators have also reported values similar to the present study (Chin et al. 1996; Ahmad et al. 2003; Ahmad et al. 2005; Najafpour et al. 2006; Vijayaraghavan et al. 2007; Wanna and Pompan 2007; AbdulKarim et al. 2011; Lam and lee 2011).

Reduction efficiency (RE \%) of COD using individual bacterial strains

Percent reduction efficiency of COD for all the isolates is presented in Fig. 1. Results revealed that reduction efficiency of COD for all the isolates is as follows: Micrococcus luteus $101 \mathrm{~PB}$ (67.19\%), Stenotrophomonas maltophilia $102 \mathrm{~PB}$ (61.92\%), Bacillus cereus $103 \mathrm{~PB}$ (78.60\%), Bacillus subtilis $106 \mathrm{~PB}(64.08 \%)$ and control $(15.63 \%)$. The strain $103 \mathrm{~PB}$ with COD reduction rate of $78.60 \%$ was the most effective followed by $101 \mathrm{~PB}$

Table 1 Characteristics of raw palm oil mill effluent (POME) and discharge standard limits

\begin{tabular}{llll}
\hline Parameters & $\begin{array}{l}\text { Raw POME } \\
(\mathrm{mg} / \mathrm{L})\end{array}$ & \multicolumn{2}{c}{$\begin{array}{l}\text { Discharge Effluent } \\
\text { standard }\end{array}$} \\
\cline { 3 - 4 } & & Malaysia & Thailand \\
\hline $\begin{array}{l}\text { Chemical oxygen demand } \\
\text { (COD) }\end{array}$ & 75,900 & - & $<1,000$ \\
$\begin{array}{l}\text { Biochemical oxygen } \\
\text { demand (BOD) }\end{array}$ & 34,393 & 100 & $<100$ \\
$\begin{array}{l}\text { Total suspended solids } \\
\quad \text { (TSS) }\end{array}$ & 14,467 & 400 & $<150$ \\
$\begin{array}{l}\text { Volatile suspended solids } \\
\text { (VSS) }\end{array}$ & 13,033 & - & - \\
$\begin{array}{l}\text { Oil \& grease (O\&G) } \\
\text { pH }\end{array}$ & 191 & 50 & $<25$ \\
\hline
\end{tabular}

All parameters are in $\mathrm{mg} / \mathrm{L}$ except $\mathrm{pH}$

Source: Malaysia: Pierzynski (2005), Thailand : Environmental Management Guideline (1997) 


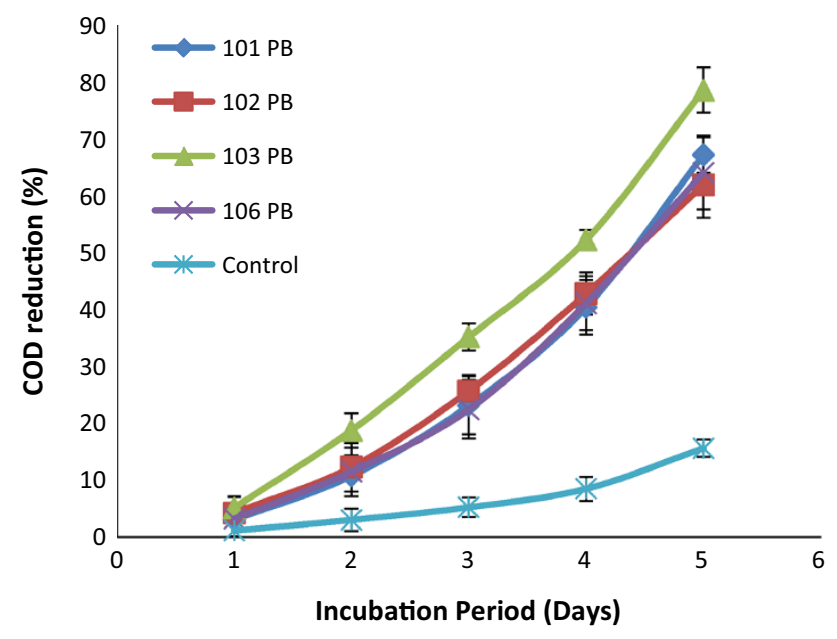

Fig. 1 Percentage reduction of COD in POME sample (pure culture)

(67.19\%), >106 PB (64.08\%) and >102 PB (61.92\%). Control reactor showed the lowest reduction efficiency compared to treatment reactors.

This suggests that our isolated strains from POME are effective for COD reduction. This study would help in understanding the role of bacteria in biological treatment of wastewaters such as those of oil processing from POME.

Comparisons of COD reduction efficiencies by bacteria isolated from POME revealed that percent reduction was similar with those results in previous publications (De Felice et al. 1997; Bhumibhamon et al. 2002; Oswal et al. 2002; Azbar and Yonar 2004; El-Bestawy et al. 2005; Takeno et al. 2005; Lan et al. 2009; AbdulKarim et al. 2011; Abass et al. 2012; Mohammed et al. 2014; Soleimaninanadegani and Manshad 2014) from oily industrial wastewaters. Thus, the findings of COD reduction appear useful for practical wastewater treatment as a compact treatment system for POME.

Reduction efficiency (RE \%) of COD using combination of bacterial strains

Percent reduction efficiency of COD for bacteria combination is presented in Fig. 2. Results revealed that reduction efficiency of COD for the bacteria combination is as follows: $\mathrm{C}_{1}$ (Bacillus cereus $103 \mathrm{~PB}$ and Bacillus subtilis $106 \mathrm{~PB}$ ) (90.64\%), $>\mathrm{C}_{2}$ (Micrococcus luteus $101 \mathrm{~PB}$ and Stenotrophomonas maltophilia $102 \mathrm{~PB})(71.84 \%)$ and $>$ control $(14.35 \%)$. The bacteria combination in reactor $\mathrm{C}_{1}$ with COD reduction rate of $90.64 \%$ was the most effective while reactor $\mathrm{C}_{2}$ recorded COD reduction of $71.84 \%$ Fig. 2. This study would help in understanding the role of mixed cultures in biological treatment of wastewaters such as those of oil processing like POME.

Comparison of the present study on bacteria combination with our pure individual bacterial culture in the

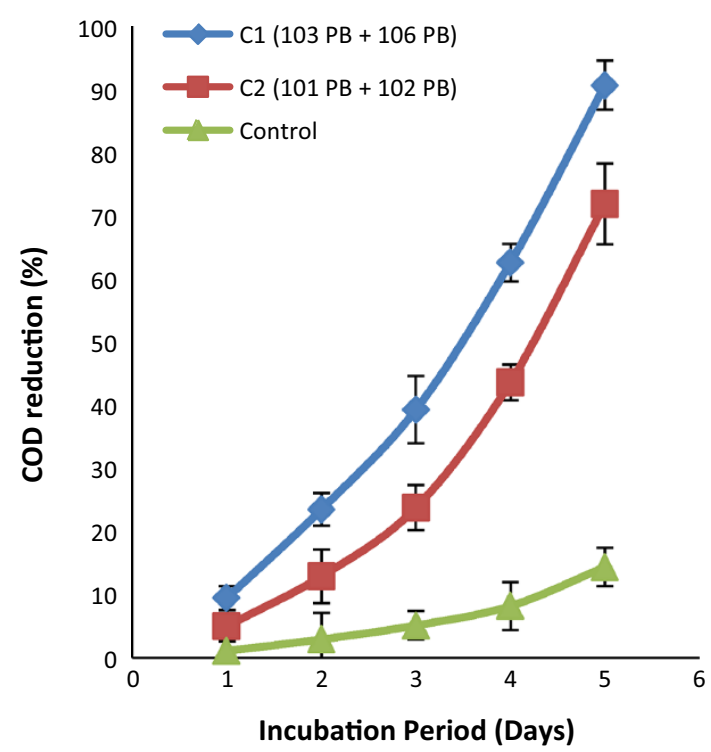

Fig. 2 Percentage reduction of COD in POME sample (mixed culture)

previous study showed that bacteria combination recorded higher COD reduction as compare to single pure culture. This suggests that bacteria combination can be used for bioremediation of environment contaminated with polluted wastewaters. El-Masry et al. (2004) have reported bioremediation of oily polluted industrial wastewater with combination of bacterial isolates.

Results revealed that using bacteria as mixed cultures produce higher reduction of parameters than pure culture. Therefore, the mixed cultures of Bacillus cereus 103PB and Bacillus subtilis 106 PB can be considered as the best bacterial mixture that exhibited the best degradation compared to the other combination mixtures. This is in good agreement with previous workers who used mixed/consortium of organisms to achieve better results (Chigusa et al. 1996; Wakelin and Forster 1997; AbdulKarim et al. 2011). Oswal et al. (2002) reported that treatment of POME with Yarrowia and then with a consortium of mixed culture of bacteria developed from garden soil produced high degradative activity. The sequential treatments brought about a significant reduction in COD. El-Bestawy et al. (2005) also reported the combination of Pseudomonas sp. and P. diminuta as mixed cultures which produced the highest activity in reducing COD from contaminated industrial effluents. Other investigators have reported higher COD reduction with mixed cultures than single cultures of microorganisms. Acinetobacter sp. (KUL8), Bacillus sp. (KUL39), and Pseudomonas sp. (Bhumibhamon et al. 2002) and Trichoderma harzianum and Penicillium (AbdulKarim et al. 2011).

In consistence with the present study, biological treatment of oil-containing wastes significantly reduced organic load (COD) (EL-Gohary et al. 1987; Martine 1991; 
Martirani et al. 1996; Odegaar et al. 1998; Raj and Murthy 1999; El-masry et al. 2004 and El-Bestawy et al. 2005). This biological treatment depends greatly on active microorganisms, which utilizes the organic substances present in the POME as nutrients and eventually degrades these organic matters into simple by-products such as methane, carbon dioxide, hydrogen sulphide and water (Jameel and Olanrewaju 2011; Jameel et al. 2011). Thus, the exploitation of these microorganisms isolated from POME for biodegradation and bioremediation purposes will offer a very efficient tool for purifying contaminated effluents water. Figures 3, 4, 5, 6 showed phylogenetic trees of the identified bacterial isolates (four bacterial isolates used for POME inoculation) from POME.

Reduction efficiency (RE \%) of BOD using individual bacterial strains

Percent reduction efficiency of BOD for all the isolates is presented in Fig. 7. Results revealed that reduction efficiency of BOD for all the isolates are as follows: Micrococcus luteus $101 \mathrm{~PB}$ (55.21\%), Stenotrophomonas maltophilia 102 PB (64.73\%), Bacillus cereus 103 PB
(90.98\%), Bacillus subtilis 106 PB (77.51\%) and control $(28.95 \%)$. The strain $103 \mathrm{~PB}$ with BOD removal rate of $90.98 \%$ was the most effective followed by $106 \mathrm{~PB}$ $(77.51 \%),>102$ PB $(64.73 \%)$ and $>101$ PB $(55.21 \%)$ compared to control reactor as illustrated in Fig. 7.

Results of BOD removal efficiencies by bacteria isolated from POME revealed that percent reduction was similar with those results in previous publications as reported by (Chin et al. 1996; El-Masry et al. 2004; El-Bestawy et al. 2005).

Reduction efficiency (RE \%) of BOD using combination of bacterial strains

Percent reduction efficiency of BOD for bacteria combination was presented in Fig. 8. Results revealed that reduction efficiency of $\mathrm{BOD}$ for the bacteria combination is as follows: $\mathrm{C}_{1}$ (Bacillus cereus $103 \mathrm{~PB}$ and Bacillus subtilis $106 \mathrm{~PB}$ ) (93.11), $>\mathrm{C}_{2}$ (Micrococcus luteus $101 \mathrm{~PB}$ and Stenotrophomonas maltophilia $102 \mathrm{~PB})(67.33 \%)$ and $>$ control $(20.81 \%)$. The bacteria combination $\mathrm{C}_{1}$ reactor that showed BOD removal rate of $93.11 \%$ was the most effective while reactor $\mathrm{C}_{2}$ recorded low BOD removal of $67.33 \%$ (Fig. 8). The finding was in agreement with
Fig. 3 Phylogenetic tree of Micrococcus luteus $101 \mathrm{~PB}$ based on 16S rRNA gene sequence comparisons

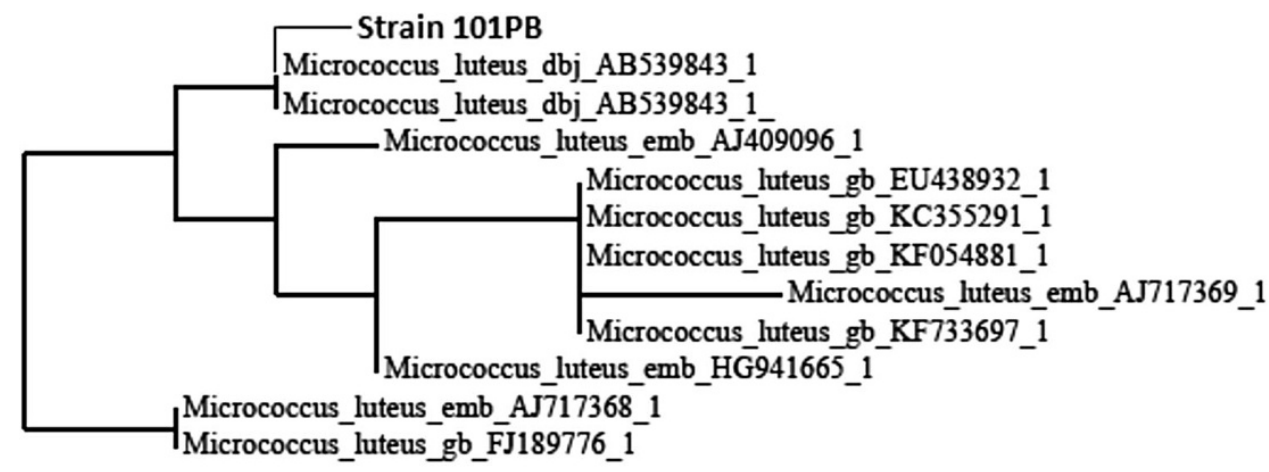

0.0003

(a) Strain 101PB

Fig. 4 Phylogenetic tree of Stenotrophomonas maltophilia 102 PB based on 16S rRNA gene sequence comparisons

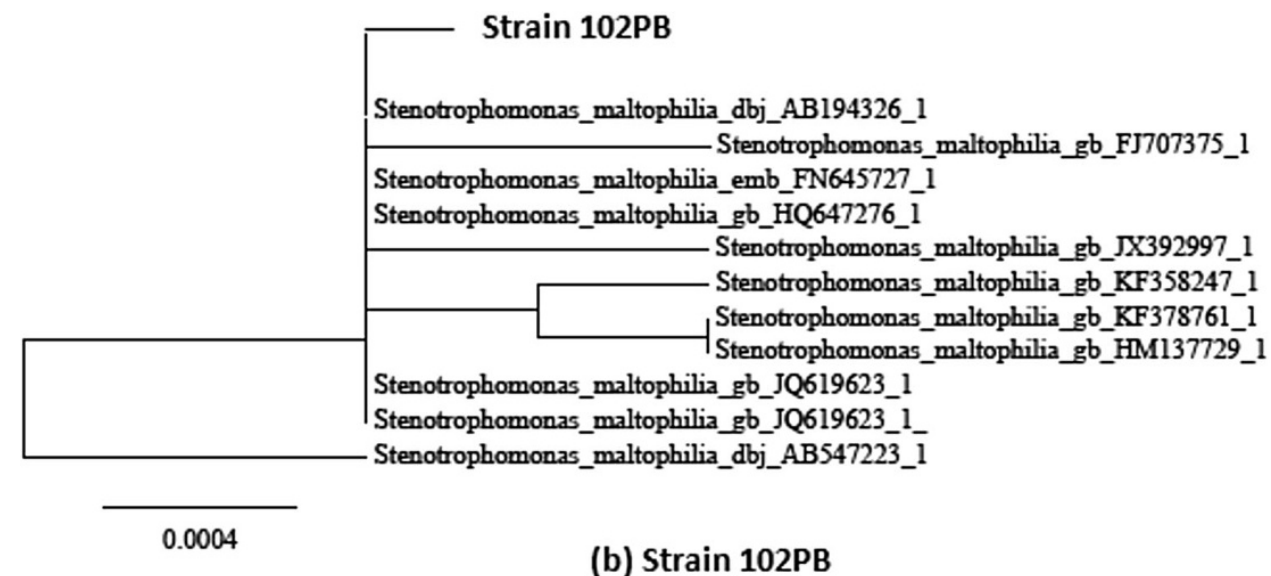


Fig. 5 Phylogenetic tree of Bacillus cereus 103 PB based on 16S rRNA gene sequence comparisons

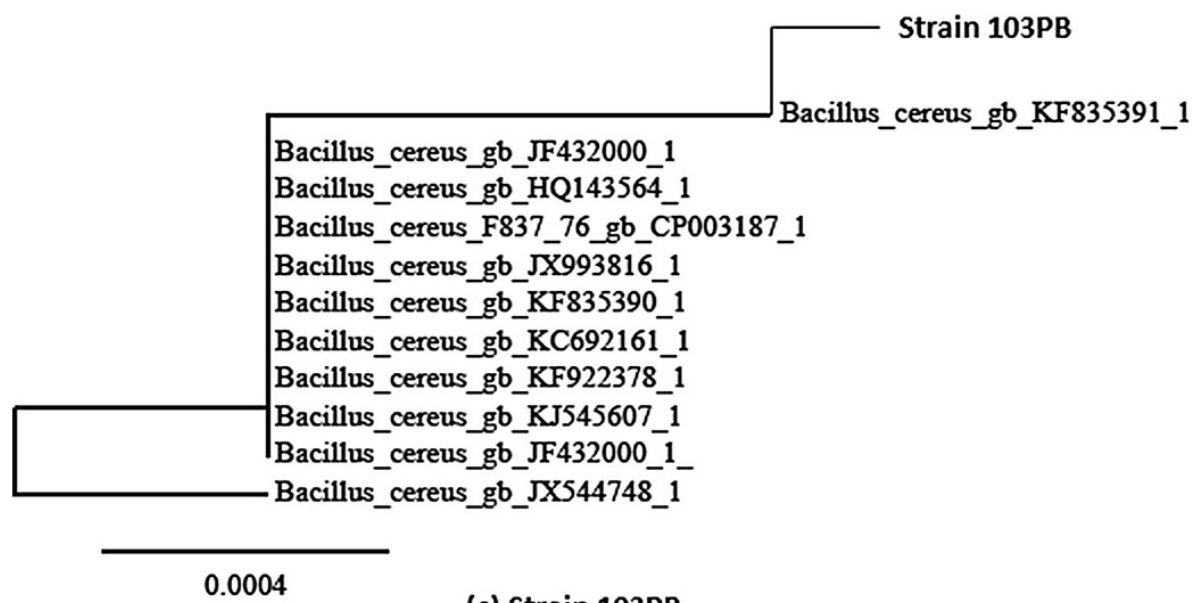

(c) Strain 103PB
Fig. 6 Phylogenetic tree of Bacillus subtilis $106 \mathrm{~PB}$ based on 16S rRNA gene sequence comparisons

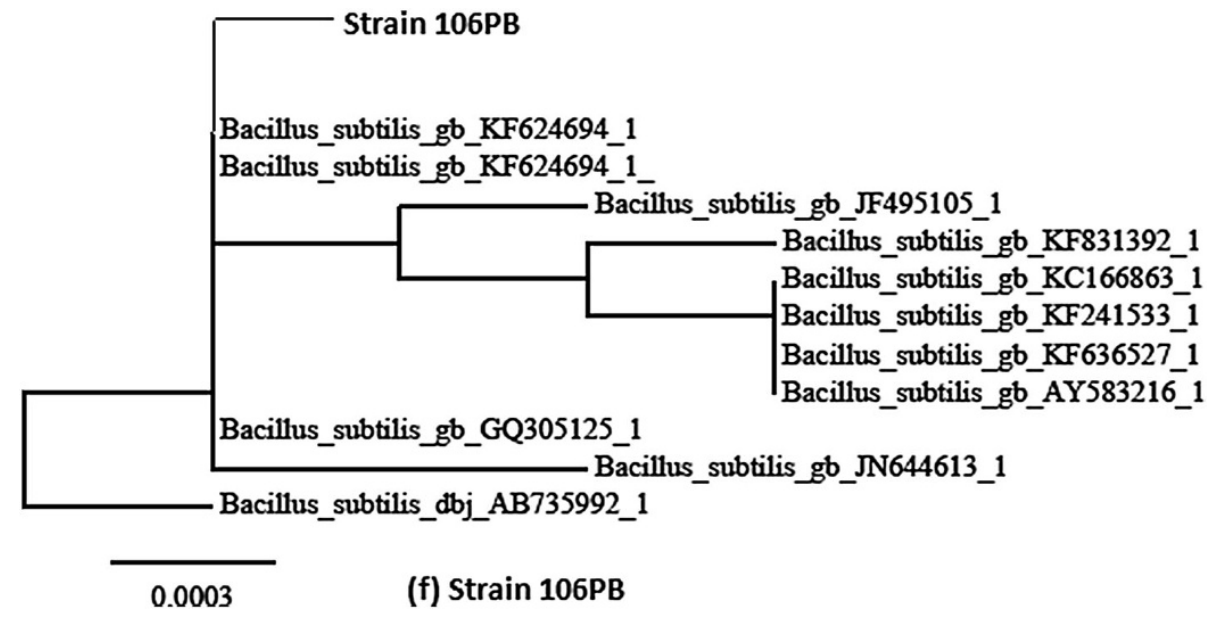

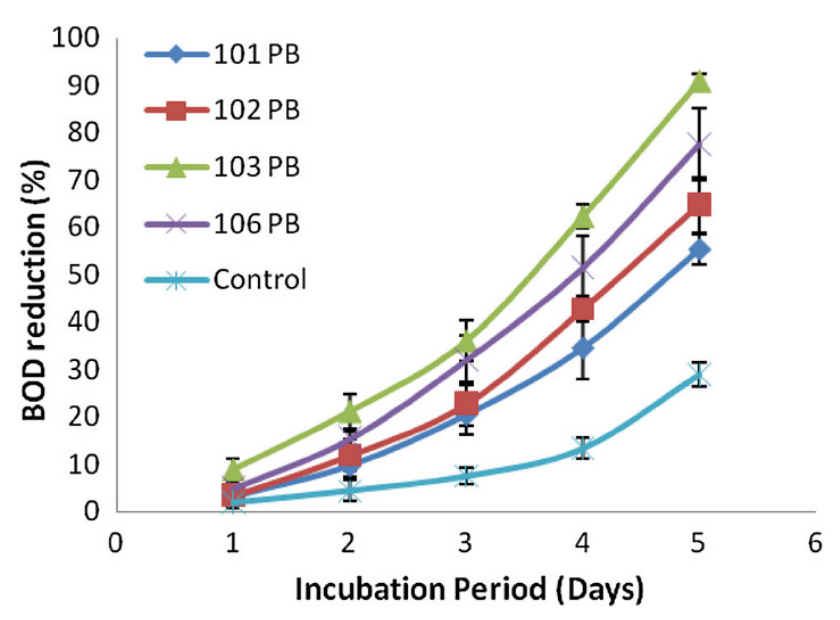

Fig. 7 Percentage reduction of BOD in POME sample (pure culture)

Qingwei et al. (1998) in their work for BOD reduction. Results of both studies revealed the effect of inoculation on organic matter biodegradation (Qingwei et al. 1998).
The synergistic effect of bacteria combination, for POME treatment brings about enhanced performance for effective biodegradation. However, synergism has been reported among mixed cultures of organisms which is attributed to the synergistic activities of the organisms Chigusa et al. (1996) and Benka-coker and Ekundayo (1997).

The composition of POME is mainly water, oil as well as cellulose wastes (Rashid et al. 2009; Ibrahim et al. 2012). This, therefore, necessitates the degradation of oil and cellulose in POME by lipase and cellulase producing bacterial. The strains (Bacillus cereus 103 PB and Bacillus subtilis $106 \mathrm{~PB})$ possess the ability to produce extracellular lipase and cellulase which stimulates better waste treatment.

During degradation, oil and cellulose in the POME are broken down and mineralized (Singh et al. 2010). Generally, microbial oil degradation in POME is considered to occur as a result of hydrolysis of oil by secretion of lipase (oil degradation enzyme), which degrades the oil to organic acids and volatile fatty acids (VFAs) or reduces it to a low molecule via beta oxidation (fatty acid degradation pathway). 
And finally, the oil is decomposed to $\mathrm{CO}_{2}$ and $\mathrm{H}_{2} \mathrm{O}$ (Koshimizu et al. 1997). Whereas cellulose degradation in POME is initiated primarily by microorganisms (fungi and bacteria) with the aid of extracellular enzymes. Cellulases are the enzymes that degraded cellulose. The enzymatic hydrolysis

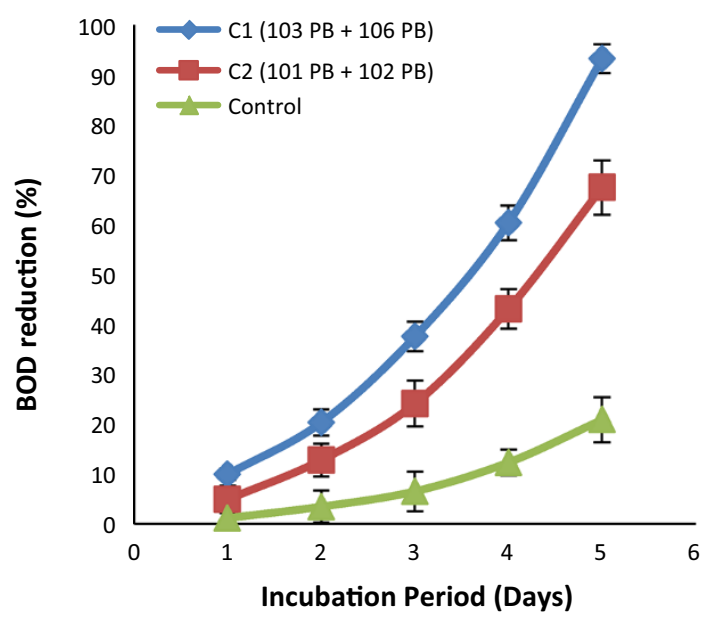

Fig. 8 Percentage reduction of BOD in POME sample (mixed culture) of cellulose requires the use of cellulase [1,4-(1,3:1,4)- $\beta$-Dglucan glucanohydrolase, EC 3.2.1.4], a multiple enzyme system consisting of endo- $1,4,-\beta$-D-glucanases $[1,4-\beta-D-$ glucanases (CMCase, EC 3.2.1.4)] also known as endoglucanases, exo-1,4,- $\beta$-D-glucanases [1,4- $\beta$-D-glucan cellobiohydrolase, FPA, EC 3.2.1.91] also known as exoglucanases and $\beta$-glucosidase (cellobiase) ( $\beta$-D-glucoside glucanohydrolase, EC 3.2.1.21); this act synergistically to convert cellulose into glucose (Lynd et al. 2002; Ray 2011). Endoglucanases hydrolyze the cellulose polymer internally at random in the amorphous site of cellulose polysaccharide chain, resulting in the formation of oligosaccharide of various lengths with a new chain ends. While exoglucanases act by removing cellobiose or glucose from both the reducing and non-reducing ends of the broken cellulose polymer, and on the other hand, $\beta$-glucosidase hydrolyses cellobiose and other cellodextrin into glucose (Lynd et al. 2002; Prado et al. 2011). Lynd et al. (2002) reported that cellulose hydrolytic enzymes are also active on hemicelluloses and hemicelluloses hydrolytic enzymes are commonly produced by cellulolytic microorganisms.

Degradation was more pronounced with mixed cultures of bacteria than with single cultures. The same findings

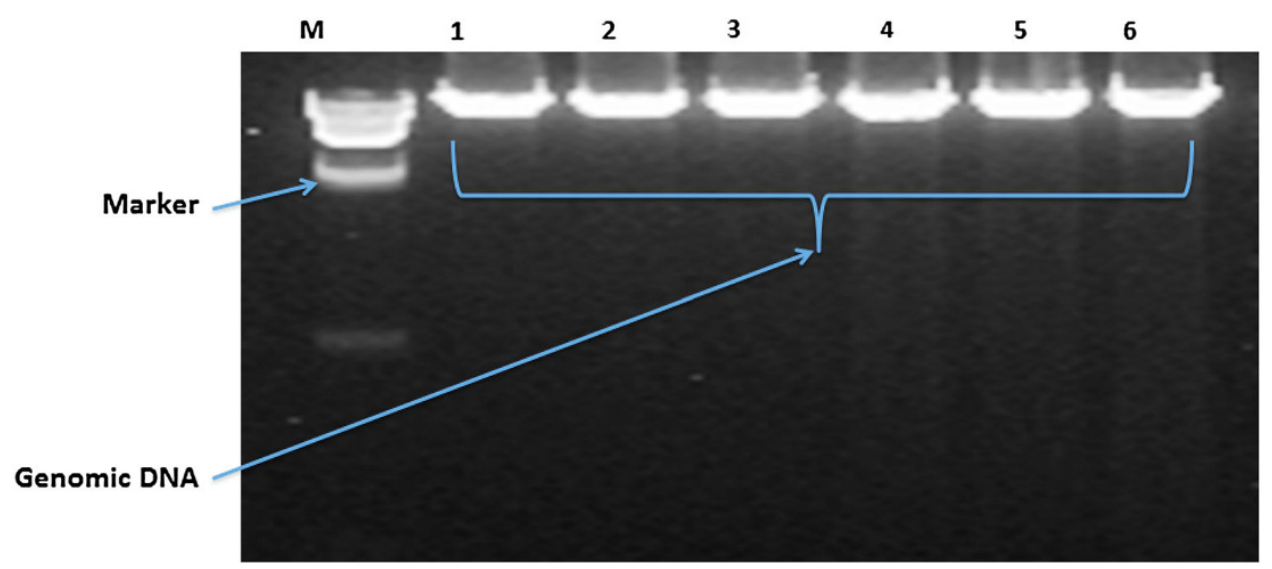

Plate 1 Gel Picture of genomic DNA: Lane 1: 101 PB; 2: 102 PB; 3: 103 PB; 4: 104 PB; 5: 105 PB; 6: 106 PB; M: Lambda/HindIII marker

Plate 2 Gel Picture of purified PCR product: Lane 1: $101 \mathrm{~PB}$; 2: 102 PB; 3: 103 PB; 4: 104 PB; 5:105 PB; 6: 106 PB; M: $1 \mathrm{~kb}$ marker (Fermentas)

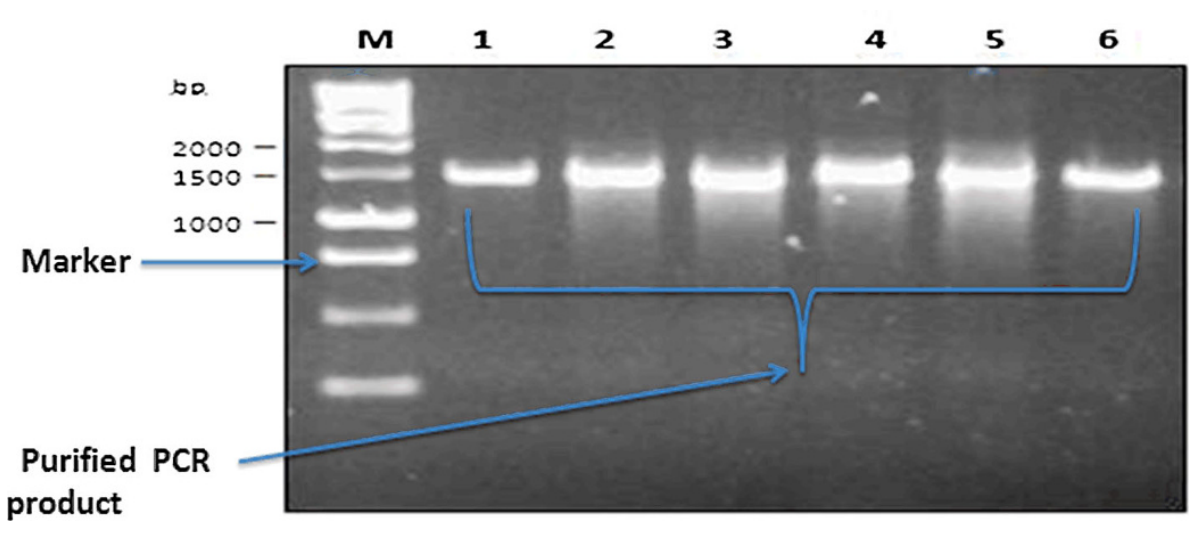


were confirmed by previous studies with mixed culture of organisms which revealed high degradative activity than with single cultures of microorganisms (Chigusa et al. 1996; Benka-coker and Ekundayo 1997 and Wakelin and Forster 1997).

In a similar study, characterization of the wastewater from food-processing plants indicated that the waste was highly contaminated with organic compounds as indicated by the high values of $\mathrm{BOD}_{5}$ (EL-Gohary et al. 1987). However, the biological treatment of oil-containing wastes significantly removed the organic load $\left(\mathrm{BOD}_{5}\right)$ in the polluted wastewater as shown also by other authors (Martine 1991; Martirani et al. 1996; Raj and Murthy 1999). In the present study, using mixed culture was more effective in reducing $\mathrm{BOD}_{5}$, which was previously indicated by Odegaar et al. (1998).

The indigenous microbial isolates from POME were observed to possess metabolic potential to degrade organic components whereas the use of mixed cultures resulted in more extensive degradation of COD and BOD than pure single cultures via one-step process under aerobic conditions.

The aerobic condition requires less hassle compared to anaerobic conditions in terms of microbial strains' sustainability (Fiestas 1984; Martine 1991). Degradation of organic load in the present study required no primary treatment (Valenzuela 1986; Tsonis 1993) and it is a onestep process. The present treatment proposal showed more advantages since no additional physical or chemical treatment was required and low energy was used. El-Bestawy et al.(2005) have reported that treatment of contaminated industrial effluents by mixed cultures of bacteria required no additional physical or chemical treatment.

\section{Conclusion}

It has been shown that the bacterial isolates from POME possess the ability to remove organic load (COD and BOD). This study would help in understanding the role of mixed culture in biological treatment of wastewaters such as those of oil processing like POME. However, a major finding of this study was that the performance of the mixed cultures could, therefore, be attributed to synergistic activities of the organisms. The mixed culture $\mathrm{C}_{1}$ (Bacillus cereus $103 \mathrm{~PB}$ and Bacillus subtilis $106 \mathrm{~PB}$ ) is the most effective bacteria and the best candidate to use in biological treatment technology of POME having the highest COD and BOD reduction rate thereby rendering the wastewater safe for effective reuse in the oil palm mills and eventual safe discharge and ultimately rendering the effluents more eco-friendly.
Authors' contributions JDB, JL \& NI: conceived and planned the experiment. JDB: carried out the experiment and drafted the manuscript. JL and NI: formulated the objectives, analyzed the data, proofread and edited the manuscript, provided guidance and improved the quality of the final manuscript. All authors read and approved the final manuscript. (Jeremiah David Bala (JDB), Japareng Lalung (JL), Norli Ismail (NI).

Acknowledgments The authors would like to thank Universiti Sains Malaysia for the financial support under Research University (RUI) Grant, No.: 1001/PTEKIND/814147.

Conflict of interests The authors declared that they have no conflict of interest.

Open Access This article is distributed under the terms of the Creative Commons Attribution License which permits any use, distribution, and reproduction in any medium, provided the original author(s) and the source are credited.

\section{References}

Abass AO, Jameel TA, Muyibi AS, Abdul Karim IM, Alam MdZ (2012) Investigation of the viability of selected microorganisms on the biodegradation of palm oil mill effluents (POME). Int $\mathbf{J}$ Chem Environ Eng 3(3): 182-186

AbdulKarim MI, Daud NA, Alam MDZ (2011) Treatment of palm oil mill effluent using microorganisms. In: Alam MDZ, Jameel AT, Amid A (eds) Current research and development in biotechnology engineering at International Islamic University Malaysia (IIUM), 3rd edn. IIUM Press, Kuala Lumpur, pp 269-275 ISBN 9789674181444

Agamuthu P, Tan EL, Shaifal AA (1986) Effect of aeration and soil inoculum on the composition of palm oil effluent (POME). Agric Wastes 15:121-132

Ahmad AL, Ismail S, Bhatia S (2003) Water Recycling from palm oil mill effluent (POME) using membrane technology. Desalination 157:87-95. doi:10.1016/S0011-9164(03)00387-4

Ahmad AL, Sumathi S, Hameed BH (2005) Residual oil and suspended solid removal using natural adsorbents chitosan, bentonite and activated carbon: A comparative study. Chem Eng J 108(1-2):179-185. doi:10.1016/j.cej.2005.01.016

APHA (2005) Standard methods for the examination of water and wastewater in 21st edn. American Public Health Association (APHA), Washington

Azbar N, Yonar T (2004) Comparative evaluation of a laboratory and full-scale treatment alternatives for the vegetable oil refining industry wastewater. Process Biochem 39(7):869-875. doi:10. 1016/S0032-9592(03)00193-6

Bala JD, Lalung J, Ismail N (2014) Biodegradation of palm oil mill effluent (POME) by bacterial. Int J Sci Res Publ 4(3):502-511

Benka-coker MO, Ekundayo JA (1997) Applicability of evaluating the ability of microbes isolated from an oil spill site to degrade oil. Environ Monit Assess 45:259-272. doi:10.1023/A: 1005774602112

Bhumibhamon O, Koprasertsak A, Funthong S (2002) Biotreatment of high fat and oil wastewater by lipase producing microorganisms. Kasetsart J Nat Sci 36:261-267

Chigusa S, Hasegawa T, Yamamoto N, Watanabe Y (1996) Treatment of waste-Chappe water from oil manufacturing plant by yeasts. Wat Sci Tech 34(11):51-58 
Chin KK, Lee SW, Mohammad HH (1996) A study of palm oil mill effluent treatment using a pond system. Water Sci Technol 34(11):119-123. doi:10.1016/S0273-1223(96)00828-1

De Felice B, Pontecorvo G, Carfagna M (1997) Degradation of waste waters from olive oil mills by Yarrowia lipolytica ATCC 20255 and Pseudomonas putida. Acta Biotechnol 17(3):231-239. doi:10.1002/abio.370170306

El-Bestawy E, El-Masry MH, El-Adl NE (2005) The potentiality of free Gram-negative bacteria for removing oil and grease from contaminated industrial effluents. World J Microbiol Biotechnol 21(6-7):815-822. doi:10.1007/s11274-004-2239-8

EL-Gohary FA, Aboelella SI, Ali HI (1987) Management of wastewater from soap and food industries: a case study. Sci Tot Environ 66:203-212. doi:10.1016/0048-9697(87)90088-X

El-Masry MH, El-Bestawy E, El-Adl NI (2004) Bioremediation of vegetable oil and grease from polluted wastewater using a sand biofilm system. World J Microbiol Biotechnol 20(6):551-557. doi:10.1023/B:WIBI.0000043162.17813.17

Environmental Management Guideline (1997) Palm oil industry. German Technical Cooperation, Thailand, p 5

Fiestas JA (1984) Directrices acutuales en la depuracion de aguas residuales de cartacter organico. Quim Ind 30:431-438

Ibrahim AH, Dahlan I, Adlan MN, Dasti AF (2012) Comparative study on characterization of Malaysian palm oil mill effluent. Res J Chem Sci 2(12):1-5

Jameel AT, Olanrewaju AA (2011) Aerobic biodegradation of oil and grease in palm oil mill effluent using consortium of microorganisms. In: Alam MDZ, Jameel AT, Amid A (eds) Current research and development in biotechnology engineering at International Islamic University Malaysia (IIUM), 3rd edn. IIUM Press, Kuala Lumpur, pp 43-51 ISBN 9789674181444

Jameel AT, Muyibi SA, Olanrewaju AA (2011) Comparative study of bioreactors used for palm oil mill effluent treatment based on chemical oxygen removal efficiencies. In: Alam MDZ, Jameel AT, Amid A (eds) Current research and development in biotechnology engineering at International Islamic University Malaysia (IIUM), 3rd edn. IIUM Press, Kuala Lumpur, pp 277-284 ISBN 9789674181444

Koshimizu S, Ohtake I, Yoshioka H, Saito Y, Taki H (1997) Development of kitchen wastewater treatment system using fats and oils degrading microorganisms. Kuuki-chouwa Eiseikougaku 71:999-1009 (in Japanese)

Lam MK, Lee KT (2011) Renewable and sustainable bioenergies production from palm oil mill effluent (POME): win-win strategies toward better environmental protection. Biotechnol Adv 29(1):124-141. doi:10.1016/j.biotechadv.2010.10.001

Lan WU, Gang GE, Jinbao WAN (2009) Biodegradation of oil wastewater by free and immobilized Yarrowia lipolytica W29. J Environ Sci 21(2):237-242. doi:10.1016/S1001-0742(08)62257-3

Lynd LR, Weimer PJ, Van Zyl WH, Pretorius IS (2002) Microbial cellulose utilization: fundamentals and biotechnology. Microbiol Mol Biol Rev 66(3):506-577. doi:10.1128/mmbr.66.3.506-577.2002

Martine AM (1991) Bioconversion of waste material to industrial products, 2nd edn. Kluwer Academic Publishers, Netherlands, p 576 ISBN 0-75140-423-3

Martirani L, Giardina P, Marzullo L, Sannia G (1996) Reduction of phenol content and toxicity in olive oil mill wastewater with the linolytic fungus Pleurotus ostreatus. Water Res 30(8):1914-1918. doi:10.1016/0043-1354(95)00330-4

Maygaonkar PA, Wagh PM, Permeswaran U (2012) Biodegradation of distillery effluent by fungi. Biosci Discov 3(2):251-258

McHugh S, O'Reilly C, Mahony T, Emer Colleran E, O'Flaherty V (2003) Anaerobic granular sludge bioreactor technology. Rev Environ Sci Biotechnol 2(2-4):225-245. doi:10.1023/B:RESB. 0000040465.45300 .97
Mohammed RR, Ketabachi MR, McKay G (2014) Combined magnetic field and adsorption process for treatment of biologically treated palm oil mill effluent (POME). Chem Eng J 243:31-42

Najafpour GD, Zinatizadeh A, Mohamed AR, Hasnain Isa M, Nasrollahzadeh H (2006) High-rate anaerobic digestion of palm oil mill effluent in an upflow anaerobic sludge-fixed film bioreactor. Process Biochem 41(2):370-379. doi:10.1016/j. procbio.2005.06.031

Odegaar H, Ruster B, Westrum T (1998) A new moving bed biofilm reactor-application and results. Water Sci Technol 19:157-165

Oswal N, Sarma PM, Zinjarde SS, Pant A (2002) Palm oil mill effluent treatment by a tropical marine yeast. Biores Technol 85(1):35-37. doi:10.1016/S0960-8524(02)00063-9

Pierzynski GM, Sims JT, Vance GF (2005) Soils and Environmental Quality, CRC Press

Piro P, Carbone M, Tomei G (2011) Assessing settleability of dry and wet weather flows in an urban area serviced by combined sewer. Water Air Soil Pollut 214(1-4):107-117. doi:10.1007/s11270010-0408-y

Prado HFD, Leite RSR, Martins DB, Gomes E, Silva RD (2011) Cellulolytic enzymes isolated from Brazilian areas: production, characterization and applications. In: Golan AE (ed) Cellulase: types and action, mechanism, and uses. Nova Science Publishers Inc, New York

Qingwei L, Mancl KM, Tuovinen OH (1998) Effect of inoculation on the biodegradation of butterfat-detergent mixtures in fixedfilm sand columns. Biores Technol 64(1):27-32. doi:10.1016/S09608524(97)00155-7

Raj SA, Murthy DVS (1999) Synthetic dairy wastewater treatment using cross flow medium trickling filter. J Environ Sci Health, Part A 34(2):357-369. doi:10.1080/10934529909376841

Rashid SS, Alam MZ, Karim MIA, Salleh MH (2009) Management of palm oil mill effluent through production of cellulases by filamentous fungi. World J Microbiol Biotechnol 25(12):2219-2226. doi:10.1007/s11274-009-0129-9

Ray RC (2011) Solid-state fermentation for production of microbial cellulase: an overview. In: Golan AE (ed) Cellulase: types and action, mechanism, and uses. Nova Science Publishers Inc, New York

Singh R, Ibrahim MH, Esa N, Iliyana M (2010) Composting of waste from palm oil mill: a sustainable waste management practice. Rev Environ Sci Biotechnol 9(4):331-344. doi:10.1007/s11157010-9199-2

Sinnappa S (1978) Studies of palm oil mill waste effluent. Malaysian Agricultural Journal 51:261-272

Soleimaninanadegani M, Manshad S (2014) Enhancement of Biodegradation of Palm Oil Mill Effluents by Local Isolated Microorganisms International Scholarly Research Notices 2014:1-8

Takeno K, Yamaoka Y, Sasaki K (2005) Treatment of oil-containing sewage wastewater using immobilized photosynthetic bacteria. World J Microbiol Biotechnol 21(8-9):1385-1391. doi:10.1007/ s11274-005-5739-2

Tsonis SP (1993) Olive oil mill wastewater abatement by anaerobic digestion followed by total evaporation. Proceeding of the International Conference on Environmental Pollution, Sitges (Barcelona), vol 2. European Center for Pollution Research, UK

Valenzuela G (1986) Thermal concentration of vegetation water. In: Proceeding of the International Symposium on Olive Byproducts Polarization (FAO), Sevilla, Spain

Vijayaraghavan K, Ahmad D, Abdul Aziz ME (2007) Aerobic treatment of palm oil mill effluent. J Environ Manag 82(1):24-31. doi:10.1016/j.jenvman.2005.11.016

Wakelin NG, Forster CF (1997) An investigation into microbial removal of fats, oils and greases. Biores Technol 59(1):37-43. doi:10.1016/S0960-8524(96)00134-4 
Wanna C, Pompan W (2007) Effect of temperature on the anaerobic digestion of palm oil mill effluent. Electron $\mathrm{J}$ Biotechnol 10(3):376-385

Wu TY, Mohammad AW, Jahim JM, Anuar N (2007) Palm oil mill effluent (POME) treatment and bioresources recovery using ultrafiltration membrane: effect of pressure on membrane fouling. Biochem Eng J 35(3):309-317. doi:10.1016/j.bej.2007. 01.029

Wu TY, Mohammad AW, Jahim JM, Anuar N (2010) Pollution control technologies for the treatment of palm oil mill effluent (POME) through end-of-pipe processes. J Environ Manage 91:1467-1490 